\title{
PENYELESAIAN SENGKETA BATAS WILAYAH DESA DINAS STUDI KASUS SENGKETA BATAS WILAYAH ANTARA DESA DINAS TULIKUP DENGAN DESA DINAS SIDAN DI KABUPATEN GIANYAR
}

\author{
Oleh: \\ Yuli Utomo ${ }^{1}$ \\ ABSTRACT
}

Village Boundary Dispute Resolution service is the application of dispute resolution regulations village boundaries under applicable rules applied to public office in the village of Gianyar regency.

This study aims to examine government policies and values - the value of local knowledge related to conflict resolution Dispute resolution limit of the village of Dinas in Gianyar regency. The results showed that completion of the boundary dispute in the village of Gianyar Regency Office is dominated by non-litigation settlement patterns, deliberation, and mediation. Thus, the principles of law, social change and the rule of law in conflict resolution need to be nurtured, preserved, and disseminated to the general public.

Keywords: Village Boundaries Dispute Resolution, Government Resolutions regulations

\section{PENDAHULUAN \\ 1. LATAR BELAKANG}

Penetapan batas desa ini sangat penting, karena menurut Pasal 2 Permendagri tersebut, Memberikan rasa aman, tertib dan terkoordinasi serta sebagai pola dasar kepastian hukumnya didalam penetapan dan penegasan batas desa.

Dalam Peraturan Menteri Dalam Negeri Nomor 27 Tahun 2006 beserta lampirannya, pengaturan tentang batas desa dan penetapannya sudah diatur dengan sangat

Mahasiswa Magister Ilmu Hukum Universitas Udayana, Denpasar,Bali. Alamat J1. Tukad Yeh Penet /Kenari Mo.4C Renon. Denpasar, e-mail : edigordo_ d1@yahoo.com rinci, mulai dari pihak mana yang berwenang menetapkan batas desa, bagaimana mekanisme penetapan batas wilayah, sampai kepada pengaturan tatacara penyelesaian perselisihan batas wilayah. Namun demikian, berdasarkan hasil penelitian pendahuluan masih saja terjadi sengketa (perselisihan) batas desa di Bali. Dalam sebuah artikel yang berjudul: "Menyelesaikan Konflik Batas Desa" Wayan P. Windia menyatakan bahwa berdasarkan pemberitaan di media massa dapat dietahui bahwa akhir-akhir ini semakin banyak muncul konflik batas desa, baik konflik desa pakraman maupun batas desa dinas. Windia memberikan contoh, bahwa dari 9 dari 12 desa dinas yang ada di Kecamatan Sukawati, Kabupaten Gianyar terbelit kasus tapal batas desa dinas. 
Melihat kenyataan tersebut, menjadi menarik untuk diteliti secara mendalam dan kritis faktor-faktor yang mempengaruhi terjadinya sengketa batas desa tersebut. Seperti diuraikan di atas, peraturan perundang-undangan yang mengatur tentang penetapan batas desa sudah sangat jelas dan rinci. Jadi untuk sementara tampak bahwa tidak ada permasalahan pada faktor hukumnya. Timbul pertanyaan: faktor-faktor apa sesungguhnya yang mempengaruhi terjadinya sengketa batas desa.

Di samping penting untuk diteliti faktor-faktor yang mempengaruhi terjadinya sengketa batas desa, hal lain yang juga relevan diteliti adalah model penyelesaian sengketa batas desa di dalam kenyataannya (empirik).

\section{Rumusan Masalah}

Dari latar belakang masalah yang telah diuraikan di atas dan kajian thesis mahasiswa yang mengkaji masalah Desa Dinas serta permasalahannya, maka dirumuskan beberapa masalah :

1. Faktor-faktor apa yang mempengaruhi terjadinya sengketa batas desa dinas di Kabupaten Gianyar?

2. Bagaimanakah pola-pola penyelesaiaan sengketa batas desa dinas di Kabupaten Gianyar?

3. Upaya-upaya apa saja yang telah ditempuh untuk mencegah terjadinya sengketa batas desa dinas di Kabupaten Gianyar?

4.

\section{Metode Penelitian}

Penelitian hukum ini termasuk penelitian hukum dengan aspek empiris, dimana hukum merupakan suatu gejala yang empiris dan dapat diamati di dalam kehidupan sehari-hari. Penelitian empiris yang oleh Soetandyo Wignjosoebroto disebutkan dengan Penelitian Non Doktrinal, yang oleh $\mathrm{R}$. Jones disebut nondoctrinal research yaitu studi pada penelitian empiris yang rnenemukan proses terjadinya dan proses bekerjanya hukum di dalam masyarakat, sebagai kajian ilmu hukum tentu saja penelitian ini tidak melupakan aspek normatif dari fungsi pemerintahan desa dinas, yakni berkaitan dengan norma-norma hukum yang mengaturnya, kajian normatif akan dilakukan mendahului kajian mengenai pelaksanaan penyelesaian sengketa batas desa dinas, untuk melihat legalitas dari penyelesaian batas desa dinas. Penelitian ini dapat dikategorikan dalam jenis penelitian dengan aspek empiris karena melihat fungsi penyelesaian sengketa batas desa yang dilaksanakan dalam kenyataannya. Tipologi penelitian ini sering disebut sebagai Socio Legal Research.

\subsection{Sifat Penelitian}

Tujuan Penelitian yang untuk menggambarkan secara rinci (deskritif analitis) dan mengkaji secara kritis pelaksanaan penyelesaian sengketa batas desa dinas dalam lingkungan pemerintahan dikabupaten Gianyar. Dalam mengkaji fungsi penyelesaian sengketa batas desa dinas ini kajian akan difokuskan pada aspek penyebab terjadinya sengketa batas desa dinas, penyelesaian sengketa batas desa dinas, dan faktor efektivitas pencegahan 
sengketa batas desa dinas dalam kenyataan sehari-hari. Dalam penelitian yang bersifat deskriptif menuangkan permasalahan dan menganalisa permasalahan yang diteliti memanfaatkan teori dan menggunakan peraturan perundang-undangan yang ada.

\subsection{Lokasi Penelitian}

Lokasi penelitiannya dan proses pengambilan data lebih di fokuskan pada masyarakat Desa Dinas Tulikup serta masyarakat Desa Dinas Sidan di Kabupaten Gianyar, pemilihan lokasi penelitian ini karena ada beberapa alasan yakni: Pertama, keduanya Desa Dinas Tulikup dan Desa Dinas Sidan bermasalah batas Desa Dinasnya, kedua, Desa Dinas Tulikup dan Desa Dinas Sidan yang kaya akan data-data yang diperlukan untuk proses penyusunan tesis.

Lokasi penelitian ini jelasnya akan dijelaskan dalam peta Desa Dinas Tulikup dan peta Desa Dinas Sidan.

\subsection{Jenis Data dan Sumber Data}

a. Jenis Data

Dalam penelitian hukum empiris ada dua jenis data yaitu data primer dan data sekunder. Data Primer adalah data yang bersumber dari penelitian lapangan yang diperoleh lansung dari sumber pertama, dan data sekunder adalah suatu data yang tidak secara langsung diperoleh dari sumber pertamanya melainkan bersumber dari penelitian kepustakaan.

b. Sumber Data

Dalam penelitian hukum empiris, kajian data dapat diperoleh dari:

a. Bahan primer, yaitu bahan-bahan materi hukum utama, yaitu:
1) Kaedah dasar atau Norma, yaitu di dalam Mukadimah Pembukaan Undang- undang Dasar 1945.

2) Peraturan dasar lainnya, yakni UUPD (UU Nomor 32 Tahun 2004 Tentang Pemerintahan Daerah)

3) Peraturan Perundangan yang terkait dengan bidang pemerintahan desa dan daerah yaitu PP No 72 Tahun 2005.

4) Hukum yang tidak tertulis seperti hukum adat.

b. Bahan hukum sekunder, yaitu materi hukum yang memberi penjabaran materi hukum utama, seperti hasilhasil penelitian, karya dari kalangan hukum maupun bukan kalangan hukum, serta literatur-literatur baik di bidang hukum maupun bukan hukum, yang terkait dengan penelitian ini.

c. Bahan hukum tersier atau penunjang, Kamus- kamus Hukum.

\subsection{Tenik Pengumpulan Data}

Saat pengumpulan data dikerjakan dengan menggunakan metode wawancara dan studi kepustakaan.

a. Metode Wawancara.

Dalam teknik wawancara ini menggunakan pedoman wawancara yang tujuan wawancara disesuaikan dengan hasil yang diinginkan peneliti. Sedangkan menurut pandangan Nanawi menyatakan bahwa dalam pengumpulan data diperlukan alat yang pas supaya data yang berkaitan dengantujuan penelitian dapat dihimpunlebih lengkap. Pengumpulan data dengan metode wawancara bersifat terbuka dan terstruktur telah dipersiapkan sebelumnya. Wawancara 
disini dilakukan terhadap responden Perbekel Desa Tulikup Ir I Gst Agung MK. Adiarta, Msi, sekretais Desa Dinas Tulikup I Dewa Putu Raka, Kaur Pemerintahan I Nyoman Mini, Kaur Pembangunan I Wayan Mustika, Kaur Umum Ngk Md Wija, BPD Tulikup I Nym Sadia, S.IP, LPM Tulikup Pnd Wayan. Wawancara dengan narasumber diatas mengenai penyelesaian sengketa batas Desa Dinas Tulikup

b. Studi Kepustakaan

Studi Kepustakaan (library research) dilakukan untuk memperoleh data sekunder yakni dengan membaca literatur yang ada kaitannyamasalahyanghendak diteliti.Bahan kepustakaan tersebut dapat berupa: buku literarur baik nasional maupun internasional, karya ilmilah, laporan penelitian, kamuskamus hukum, ensiklopedia dan dokumendokumen yang relevan dengan permasalahan yang akan diteliti. Nasution mengatakan bahwa kajian kepustakaan bermanfaat untuk melakukan penelusuran dan penelaah refrensi. Sebagai alat dalam pengumpulan data sekunder selain peneliti sendiri, juga digunakan alat bantu yang oleh Maleong disebut catatan lapangan (field notes) catatan lapangan tersebut berisi ringkasan-ringkasan informasi yang berhasil dijaring.

\subsection{TeknikPenentuan SampelPenelitian dan Informan}

Teknik penentuan sampel yang, dipergunakan dalam penelitian ini adalah teknik non probability sampling dimana jumlah sample tidak harus mewakili jumlah pupolasi. Sampel yang dipilih adalah sampel yang didasarkan pada kesamaan ciri dengan populasi. Dalam teknik non probability, sample maupun jumlah angka tidak akan mampu prosentasenya. Penelitian akan dihentikan apabila dianggap telah mewakili seluruh obyek penelitian. Populasi dalam penelitian ini adalah Masyarakat Desa Dinas Tulikup dan Masyarakat Desa Dinas Sidan. Penetapaninformandilakukansecarapurposif dengan terlebih dahulu mencari informan pangkal. Informan yang akhirnya ditetapkan adalah Kepala Urusan Pemerintahan Desa Kabupaten Gianyar, informan pangkal ini kemudian akan merekomendasikan informasi kunci (key informan) dengan alasan bahwa masyarakat Desa Dinas terdiri dari beberapa Dusun. Informasi kunci selanjutnya merekomendasikan informasi berikutnya yang dijaring dengan penerapan teknik bola salju (snow bowling) dan penetapan informan baru diakhiri setelah terjadi kejenuhan informasi.

\subsection{Analisis Data dan Pengolahan}

a. Pengolahan Data

Langkah di dalam Pengolahan data :

Semua data yang diperoleh dari hasil penelitian di lapangan dilakukan pengeditan dengan tujuan untuk memilah mana data yang bisa dipergunakan dan mana yang tidak, sesuai dengan permasalahan yang ada. Setelah dilakukan editing, berikutnya proses coding, di dalam proses ini di lakukan pengklasifikasi semua jawaban- responden yang sesuai ketentuan yang diinginkan.

b. Analisis Data

Dalam penelitian ini, analisis yang diterapkan adalah analisis kualitatif atau yang merupakan pemahaman keseluruhan menurut penulis. 


\section{HASIL DAN PEMBAHASAN}

\subsection{Aspek Kewilayahan Desa Dinas}

Desa dalam system pemerintahan Negara Kesatuan Republik Indonesia adalah kesatuan masyarakat hukum yang memiliki batas-batas wilayah, dan berwenang mengatur, mengurus kepentingannya sendiri berdasarkan asal usul dan adat istiadat yang diakui dan dihormati, di dalam (Permendagri No.27/2006 : Pasal 1, ayat 3). Berdasarkan pengertian ini, desa terdiri dari tiga unsur, yaitu (1) penduduk atau kesatuan masyarakat yang mempunyai kewajiban dan hak di dalam hukum, (2) wilayah desa yang ditandai dengan batas-batas yang memisahkan secara administratif dengan wilayah lain dan (3) pemerintahan desa yang berfungsi untuk mengatur dan mengurus kepentingan masyarakat setempat. Wilayah merupakan unsur yang sangat penting bagi desa, oleh karena itu batas-batas wilayahnya harus jelas dan tegas. Ketidakjelasan dan ketidak tegasan batas sering menimbulkan konflik karena tidak ada kepastian hukumnya. Urusan kewenangan Pemerintahan Desa satu dengan Desa lainnya, dipisahkan secara yurisdiksi melalui Batas Desa (Permendagri No. 27/2006 : Pasal 1, ayat 9). Untuk memberikan kepastian hukum yang bersifat tegas terhadap batas-batas desa diperlukan penegasan dan penetapan batas- batas desa (Permendagri No.27/2006 : Pasal 2). Agar penegasan dan penetapan batas desa dapat berjalan tertib, terkoordinasi dan benar maka dalam pelaksanaannya harus sesuai dengan PERMENDAGRI No 27 TH.2006.
Batas-batas wilayah ini bagi desa mempunyai peran penting sebagai pemisah wilayah penyelengaraan kewenangan, dan pemerintahan suatu desa dalam batas yuridiksi wilayah. Oleh karena itu, kegiatan

Penegasan, penetapan batas desa dinas sangat diperlukan untuk kepastian hukumnya.

\subsection{Aturan Kewilayahan Desa Dinas}

Membentuk desa harus memenuhi syarat. Syarat - syarat pembentukan desa antara lain: wilayah kerja, sarana dan prasarana, jumlah penduduk, luas wilayah dan bagian wilayah. Pemerintah desa terdiri dari kepala desa. Sekretaris desa, perangkat desa, secretariat desa, pelaksana kerja, teknis lapangan, dan unsur unsur kewilayahan.

Dalam Perda No.21Th.2006 menyatakan bahwa pemerintahan desa dan Badan Pemusyawaratan Desa/ BPD merupakan penjelmaan Pemerintahan Desa yang di tindak lanjuti dengan Perda No 01 Th 2008 Tentang Pembentukan LembagaLembaga Desa fungsinya sebagai Mitra pemerintahan masyarakat Desa.

\subsection{Realitas Kewilayahan Desa Dinas}

Makna wilayah merupakan satu kesatuan yang tidak bias dilepaskan dari tujuan awalnya pendirian desa. Istilah wilayah dapat digunakan untuk skala sempit dalam lingkungan tetangga hingga skala luas dalam pergaulan internasional. Yang dimaksudkan wilayah merupakan tempat tertentu secara geografis yang mempunyai ciri khas tertentu, berlokasi, serta melakukan interaksi. Kata ciri tertentu dalam pengertian tersebut memiliki arti penting dan kritikal 
karena berhubungan dengan tujuan analisis sekaligus tujuan perencanaan. Itu sebabnya batasan georafis suatu wilayah desa dinas menjadi longgar ketika tujuan analisis hanya mencakup suatu desa dinas maka hanya disitulah batasannya. Sebaliknya ketika menghendaki analisis mencakup wilayah kecamatan batasannya bisa mencapai seluruh wilayah Kabupaten.

Dalam menganalisis wilayah secara umum dikenal tiga tipe. Pertama, wilayah fungsional (Functional Region), Wilayah tipe ini dicirikan oleh adanya derajad integrasi antara komponen-komponen di dalamnya yang saling berinteraksi kedalam wilayah dibandingkan berinteraksi ke wilayah luar. Terbentuknya wilayah fungsional ini akan tampak dalam keadaan pelaku-pelaku ekonomi local saling berinteraksi di antara mereka sendiri pada derajad atau tingkatan (kualitas dan kuantitas) lebih dari interaksi pelaku ekonomi lokal dengan pelaku dari luar wilayah.

Kedua, wilayah homogen. Wilayah homogeny dicirikan oleh adanya relative, kesamaan (similaritif) dalam wilayah, Kesamaan ciri tersebut dapat dilihat dari aspek sumberdaya alam (misalnya iklim dan komoditi) : social (agama, suku, kelompok ekonomi), maupun ekonomi (sektor ekonomi), Beberapa istilah yang mengacu ke wilayah homogen misalnya wilayah Bukit, wilayah kumuh, wilayah miskin, wilayah elite, wilayah jasa, wilayah pantai.

Ketiga, Wilayah Administratif. Wilayah ini dibentuk untuk kepentingan pengelolaan atau organisasi oleh pemerintah maupun pihak-pihak lain. Batas wilayahnya secara geografis administrative sering dianggap lebih penting dari dua tipe lainnya karena lebih sering digunakan sebagai daar perumusan kebijakan, Pembagian Wilayah berdasarkan Provinsi, Kota, Kabupaten, kecamatan dan pedesaan. Wilayah administrative sering menjadi penentu berkembangnya wilayah homogeny bahkan wilayah fungsional.

\subsection{Mekanisme Penyelesaian Batas Wilayah}

Secara garis besar penetapan dan penegasan batas Desa Tulikup dan Desa Sidan dilakukan melalui tahap, yaitu penetapan, penegasan batas desa. Batas Desa Penetapannya dilakukan secara penelitian document, peta dasar, dilinasi batas, diatas peta dasar. Sedangkan penegasannya melalui; penentuan document, pelacakan garis batas, pasang pilar, batas. Dan pembuatan peta batas wilayah desa. Mengingat segmen-segmen batas Desa Tulikup dan Desa Sidan cukup kompleks sehingga tidak memungkinkan dilakukan secara kartometrik, maka segmensegmen batas harus didelineasi langsung di lapangan dengan menggunakan teknologi GPS. Selain untuk penentuan segmensegmen batas, pemanfaatan teknologi GPS juga digunakan untuk pengukuran dan penentuan posisi pilar-pilar batas. Adapun metode pengukuran dilakukan secara radial yang diikatkan terhadap titik TDT No : 12.20.027 Orde 3 BPN. Pekerjaan penetapan dan penegasan batas Desa Tulikup dan Desa Sidan, Kabupaten Gianyar, Propinsi Bali telah memenuhi spesifikasi yang disyaratkan 
menurut Permendagri No.27 Tahun 2006. Hal ini ditunjukkan dengan tingkat ketelitian koordinat pilar-pilar batas berkisar antara 7,4 mm - 0,8 mm, dan ketelitian planimetris garis batas wilayah desa sebesar $0,06 \mathrm{~mm}$ dengan skala $1: 5000$.

Batas desa adalah batas pemisah wilayah antar desa yang saling bersebelahan. Batas pemisah tersebut dapat berupa batas alam maupun batas buatan manusia. Unsur-unsur alam yang sering digunakan sebagai batas pemisah wilayah desa antara lain sungai, watershed, danau; sedangkan batas buatan manusia berupa : Irigasi saluran air, jalan raya, maupun Rel Kereta api. (Permendagri No.27/2006 : Pasal 1). Batas wilayah desa didefinisikan sebagai urusan kewenangan pemerintah desa satu dengan desa lainnya dipisahkan secara yurisdiksi melalui batas-batas desa (Permendagri No.27/2006 : Pasal 1). Tujuan dilakukannya, penegasan, penetapan untuk kepastian hukumnya. No.27/2006 : Pasal 2).Pelaksanaan penetapan dan penegasan batas wilayah desa harus mengacu pada Peraturan Menteri Dalam Negeri Nomor 27 Tahun 2006 tentang Penetapan, penegasan batas desa dilakukan dengan rangkaian penentuan document Sedangkan penegasannya melalui; penentuan document, pelacakan garis batas, pasang pilar, batas. Dan pembuatan peta batas wilayah desa. pilar batas, serta pembuatan peta batas wilayah. Tahapan penetapan dan penegasan batas desa dilakukan berdasarkan prinsip-prinsip geodesi. Menurut Permendagri No.27/2006, proses penetapan ini terdiri atas tiga tahapan kegiatan, yakni penelitian dokumen batas, penentuan peta dasar dan pembuatan peta.

Desa secara kartometrik. Dokumendokumen batas tersebut antara lain :

1. Perundang-undangan dan peraturan lainnya tertulis/ tidak tertulis. tentang pembentukan batas desa yang bersangkutan.

2. Peta administrasi desa yang telah ada.

3. Peta desa yang sudah ada.

4. Peta lainnya, seperti: peta rupabumi, peta topografi, peta pajak bumi dan bangunan, peta pendaftaran tanah, peta laut dan citra satelit,

5. Data lainnya dan dokumen sejarah.

Peta-petayang dapat digunakan sebagai peta dasar peta dasar menggambarkan batas desa secara kartometrik, yaitu peta rupabumi, peta topografi, peta pajak bumi dan bangunan, peta pendaftaran tanah, peta laut maupun citra satelit. Selanjutnya pembuatan peta penetapan batas desa secara kartrometrik dibuat dengan spesifikasi sebagai berikut :

Tabel 3.Spesifikasi Teknis Pemetaan Wilayah Desa

\begin{tabular}{|l|l|}
\hline No & Jenis Persyaratan \\
\hline 1 & Datum Horisontal DGN 95 \\
\hline 2 & Elipsoid Referensi WGS 1984 \\
\hline 3 & Skala Peta 1:1.000 - 1: 10.000 \\
\hline 4 & Sistem Proyeksi Peta Transverse Mercator (TM) \\
\hline 5 & $\begin{array}{l}\text { Sistem Grid Universal Transverse Mercator (UTM) dengan grid } \\
\text { geografis dan metrik }\end{array}$ \\
\hline
\end{tabular}

Penegasan batas wilayah desa dilakukan dengan menggunakan dasar unsur unsur alam dan buatan manusia. Jika peraturan yang mengatur tentang batas desa tidak jelas sehingga digunakan aturan sebagai berikut: 
1. Pemanfaatan batas alam seperti sungai, watershed, dan danau,

2. Penggunaan batas karya manusia seperti salauran air sebagai irigasi, rel kereta api, jalan raya dan pilar batas (koordinat-koordinat batas).

Penggunaan sungai dan danau sebagai batas desa juga harus jelas apakah pinggir sungai, tengah sungai atau thalweg, demikian juga penggunaan jalan dan saluran irigasi apakah dipinggir atau tengah.

\subsection{Prinsip-prinsip Penentuan Batas Unsur Alam}

Pada unsur sungai, penentuan batas dapat dilakukan pada pinggir sungai, tengah sungai ataupun thalweg. Gambar 1 menunjukkan prinsip penentuan batas dengan prinsip membagi 2 sama besar lebar sungai. Garis batas pada sungai adalah garis imajiner (garis putus-putus).

Penentuan batas pada sungai dengan prinsip bagi 2 sama besar lebar Batas yang berpotongan dengan sungai yaitu P1 dan P2 dipasang pilar untuk mengetahui awal/ akhir perpotongan garis batas dengan sungai tersebut. Pemasangan pilar harus pada lokasi yang stabil. Pilar batas tidak dapat dipasang tepat di perpotongan garis tengah sungai dengan pinggir sungai karena umumnya kondisi tanahnya labil. Jarak dari pilar P1 diukur ke tepi sungai terdekat dan ke tepi sungai terjauh, serta arahnya juga diukur. Demikian pula untuk pilar P2.

Pada watershed, ketentuan-ketentuan penentuan batas adalah:

1. Batas Garis janganmelaluiperpotongan sungai.
2. Jika terdapat lebih dari satu garis pemisah air maka garis batasnya adalah garis pemisah air yang terpendek.

\subsection{Prinsip-prinsip Penentuan Batas Unsur Karya Manusia}

Untuk batas jalan raya, rel kereta api, saluran air pada irigasi, dan kanal, menggunakan tepi yang merupakan batas wilayah antara kedua desa yang berbatasan sesuai kesepakatan dua desa yang berbatasan. Penentuan batas yang didasarkan pada as jalan.

Untuk jalan yang digunakan sebagai batas, maka garis batasnya adalah pada perpotongan as/sumbu jalan tersebut. Untuk mengetahui as jalan maka perlu dipasang Pilar Kontrol Batas (PKB) terutama pada belokan jalan, atau pada perpotongan jalan untuk menentukan posisi garis batas (as jalan) tersebut, kemudian diukur ke kedua tepi jalan untuk mengetahui lebar jalan.

Garis batas pada pertigaan jalan, terkhusus batas yang berada di pertigaan jalan, sehingga diperlukan Pilar Kontrol Batas dan Pilar Batas untuk menentukan posisi batas dipertigaan jalan tersebut. Penempatan pilar-pilar harus memperhatikan kemungkinan adanya pelebaran jalan. Selanjutnya, dilakukan pengukuran jarak dan sudut dari ke-3 pilar tersebut ke titik perpotongan garis batas antara desa $\mathrm{A}$, desa $B$ dan Desa C di titik P1 perlu dibuatkan peta situasi dengan skala peta 1:1.000.

\subsection{Aplikasi teknologi GPS}

dalam penetapan dan penegasan batas desa Teknologi GPS dalam proses kegiatan penetapan dan penegasan batas wilayah desa 
mempunyai manfaat yang cukup penting, yaitu penentuan posisi pilar-pilar batas desa, dan penentuan titik-titik batas desa. Beberapa hal yang harus diperhatikan dalam penentuan posisi pilar batas dengan metode ini, yaitu :

1. Pengamatan GPS harus menggunakan metode diferensial.

2. Minimal menggunakan 2 receiver GPS tipe geodetic.

\subsection{Kegiatan Fasilitasi Penyelesaian Batas Wilayah Administrasi Antar Desa}

1. Latar Belakang Kegiatan

Kegiatan Fasilitasi Penyelesaian Batas Wilayah administrasi antar desa dimana kegiatan ini telah dianggarkan pada anggaran induk tahun 2011 dengan anggaran Rp. 20.000.000,- dan dilanjutkan lagi pada tahun 2012.

2. Maksud dan Tujuan Kegiatan

Fasilitasi Penyelesaian Batas Wilayah administrasi antar Desa meningkatkan pengetahuan desa tentang batas wilayah administrasi antar desa terselesaikannya masalah batas wilayah adaministrasi di desa yang bermasalah

3. Sasaran Kegiatan

Adapun sasaran kegiatannya adalah Terfasilitasinya penyelesaian batas wilayah antar desa secara administrasi sehingga dapat membantu masyarakat dalam penentuan batas wilayah administrasi.

\section{Target/Volume Kegiatan}

Target dari kegiatan ini adalah 7 Kecamatan di Kabupaten Gianyar.
5. Lokasi Kegiatan

7 (tujuh) Kecamatan di Kabupaten Gianyar.

1. Waktu Pelaksanaan Kegiatan

Selama 12 bulan selama 1 tahun pada kegiatan tahun 2012.

7. Input

Dana berasal dari APBD Kabupaten dengan pelaksananya adalah Pegawai di Bagian Pemdes dan Tim Pembina.

8. Output

$$
\text { Dana yang dapat dipakai 100\%. }
$$

9. Outcome

Terwujudnya Batas Wilayah yang jelas antar desa di kabupaten Gianyar.

10. Rencana Angaaran Biaya (RAB)

a. Belanja pegawai

$$
\text { : Rp10.000.000 }
$$

b. belanja barang dan jasa

$$
\text { : Rp 40.000.000 }
$$

Total anggaran

$$
\text { Rp50.000.000 }
$$

\section{PENUTUP}

1. Simpulan

1. Faktor Perubahan Sosial yang terjadi pada perkembangan masyarakat Desa Dinas Tulikup dan Desa Dinas Sidan dengan berjalannya Pembangunan dan dinamika masyarakatnya sangat berpengaruh dalam proses penyelesaiaian sengketa Batas desa dinas di daerah masing-masing terutama di daerah desa dinas di Kabupaten Gianyar.

2. Pola-pola penyelesaiaan sengketa batas desa dinas di Kabupaten Gianyar 
mengikuti pelaksanaan Undang-

Undang yang berlaku disamping tidak melupakan musyawarah mufakat untuk mencari solusi yang terbaik.

3. Upaya-upaya yang telah ditempuh untuk mencegah terjadinya sengketa batas desa dinas di Kabupaten Gianyar , melalui pemerintahan desa di kabupaten Gianyar Gencar melakukan proses pengenalan sosialisasi yang mendalam mengenai pentingnya pengenalan Batas desa Dinas guna kepentingan kedepan masyarakat desa dinas di kabupaten Gianyar khususnya dan Bali pada umumnya merupakan gerakan terobosan yang cukup berhasil menekan terjadinya permasalahan batas desa dikemudian hari.

\section{Saran}

1. Kiranya Pemerintah Kabupaten Gianyar bisa lebih terbuka lagi dengan peneliti di daerah dan tidak berusaha menghambat peneliti dalam melakukan kajian ilmiah penelitian didaerah Kabupaten Gianyar.

2. Banyak masalah yang dibiarkan penanganannya karena alasan sumber daya / sumber dana untuk melakukan proses musyawarah berkelanjutan yang mampu membawa keberhasilan nantinya.

3. Mencegah terjadinya permasalahan batas desa lebih utama dari pada sampai terjadinya permasalahan Batas desa Dinas yang berlarut-larut demi kesinambungan proses pembangunan masyarakat umumnya.

\section{DAFTAR PUSTAKA}

I Gde Parimartha, 2003. "Orasi Ilmiah, Memahami Desa Dinas dan Desa Pakraman Suatu Tinjauan Historis Kritis”, Universitas Udayana, Denpasar.

Soetardjo Kartohadikoesoemo, 1984, Desa, PN.Balai Pustaka, Jakarta.

Rafles, 1978, The History of Java, Volume I , Oxford University Press. Kuala Lumpur.

F.W.F,Hunger,1982,Desa Adat dan Desa Pemerintahan.(terjemahan I Wayan Dangin).

I Made Pasek Diantha, 2001, “Eksistensi

Desa Menurut UU No. 22

Tahun 1999",Makalah dalam

Seminar Pemerintahan Desa

yang diselenggarakan oleh FISIP Warmadewa.

I Wayan P. Windia, 2011, Menyelesaikan

Konflik Batas Desa,Bali Post, 24 Maret 2011

Artadi dan Wiryawan, 2009. Penyelesaian Sengketa di Luar Pengadilan, Udayana University.

IWayan Suteja, PengaturanPenyelenggaraan Pemerintahan Desa di Kabupaten Badung,Tesis Program Pasca Sarjana Program Studi ilmu Hukum Unud Denpasar.

I Made Suprata, Sinkronisasi Desa Pakraman Dan Desa Dinas Dalam Peyelenggaraan Pemerintahan Desa Di Kabupaten Karangasem Propinsi Bali, Tesis Program Pasca Sarjana 
Program Studi ilmu Hukum Unud Denpasar.

Ni Nyoman Suadnyani, Kedudukan Desa Adat dan Desa Dinas Dalam Kerangka Otonomi Desa Di Bali, Tesis Program Pasca Sarjana Program Studi ilmu Hukum Unud Denpasar.

I Made Bagia, Sinergi Serta Kerjasama antara Desa Dinas dan Desa Pakraman Dalam Menangani Kehadiran Penduduk Pendatang di Kota Denpasar, Tesis Program Pasca Sarjana Program Studi ilmu Hukum Unud Denpasar.

I Ketut Wirta Griadi, Konflik Adat di Bali, Suatu Studi Hukum dan Perubahan Sosial, Tesis Program Pasca Sarjana Program Studi ilmu Hukum Unud Denpasar.

I Gede Suartika, Konflik Adat di Desa Pakraman Pengosekan, Desa Mas, Ubud, Gianyar: Perspektif Kajian Budaya,Disertasi Program Pasca Sarjana Universitas Udayana Denpasar.

A.Javier Trevino 2010 .The Sociology of Law Classical and Contemporary Perspectives.Transsaction Publisers New Brunswick (USA) and London (UK).

Toneko, Soleman B, 1993. Pokok-Pokok Study Hukum Dalam Masyarakat, PT. Gramedia Pustaka Utama, Jakarta.

Soekamto, Soerjono, 1993, PendekatanPendekatan Sosiologi Terhadap Hukum, Bina Aksara, Jakarta.

Soekamto, Soerjono, 1991, Fungsi Hukum dan Perubahan Sosial, PT.Citra Aditya.Bandung.

Yekezel Dror, 1970.Law as a Tool of Directed Social Change Framework for policy Making.Edited by : Stuart S.Nagel, Sage Contempory Social Change Issues 3 Law and Social Change.London.

Astiti, Tjok Istri Putra, 2010, Desa Adat Menggugat dan di Gugat. Udayana University Press, Denpasar.

A.Javier Trevino 2010 .The Sociology of Law Classical and Contemporary Perspectives.Transsaction Publisers New Brunswick (USA) and London (UK).

Artadi dan Wiryawan, 2009,Penyelesaian Sengketa di Luar Pengadilan, Udayana University Press, Denpasar.

HAW.Widjaja, 2003,Otonomi Desa,PT. Radja Grafindo Persada,Jakarta.

Program Studi Magister Ilmu Hukum Program Pascasarjana Universitas Udayana, 2005, Pedoman Penulisan Usulan Penelitian dan Penulisan Tesis Ilmu Hukum Program Studi Magister Ilmu Hukum Program Pascasarjana Universitas Udayana.

E. Jones, 1962, Cureent Trends in Legal Research, (Expert), Journal of Legal Education.

NiKetut Supasti Dharmawan, 2005, "Metode Penelitian Hukum Empiris", makalah dalam Lokakarya Metode Penelitian Hukum Empiris yang diselenggarakan oleh Program Magister Ilmu Hukum Program Pascasarjana Universitas Udayana. 
(UDAYANA MASTER LAW JOURNAL)

Bambang Sunggono, 2005, Metode Penelitian Hukum, PT. Raja Grafindo Persada, Jakarta.

Program Studi Magister Ilmu Hukum

Program Pascasarjana Universitas

Udayana. 2009.Pedoman Penulisan

Usulan Penelitian Dan Tesis.

Nanawi Hadari dan Martini Hardari, 1992, Instrument Penelitian Bidang Sosial, Gajah Mada University Press, Yogyakarta.

S. Nasution, 2003, Metode Research

(Penelitian Ilmiah), Bumi Aksara, Jakarta.

Lexy J. Maleong, 1994, Metodologi

Penelitian Kuantitatif, PT. Remaja

Rosadakarya, Bandung.

Satjipto Rahardjo,1980, Hukum dan Masyarakat,Penerbit Angkasa, Bandung,

Soerjono Soekanto,1976, Beberapa

Permasalahan Hukum dalam

Kerangka Pembangunan di Indonesia, Yayasan Penerbit UI, Jakarta.

Ralf Dahrendorf, 1986, Kelas dan Konflik Kelas dalam Masyarakat Industri, Sebuah Analisa Kritik, Rajawali, Jakarta. 